\title{
ANALYSIS OF CATTLE FARMER EXCHANGE RATE (NTP-T) AND THE FACTORS THAT INFLUENCE IT IN SIDOARJO REGENCY
}

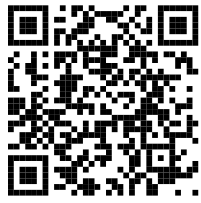

\author{
Pawana Nur Indah ${ }^{1}$, Indra Tjahaja Amir ${ }^{1}$ and Sudiyarto ${ }^{1}$ \\ ${ }^{1}$ Departement Agribusiness, UPN "Veteran" Jawa Timur, Indonesia
}

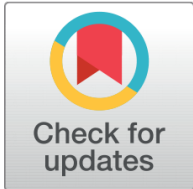

Published 11 May 2021

Corresponding Author

Pawana Nur Indah, Pawana_ni@u

pnjatim.ac.id

DOI $10.29121 /$

ijetmr.v8.i5.2021.934

Funding: This research received no specific grant from any funding agency in the public, commercial, or not-for-profit sectors.

Copyright: (C) 2021 The Author(s). This is an open access article distributed under the terms of the Creative Commons Attribution License, which permits unrestricted use, distribution, and reproduction in any medium, provided the original author and source are credited.

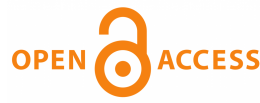

\section{ABSTRACT}

Farmer Exchange Rate (NTP) is a proxy indicator or an indicator of the approach to the welfare level of breeders. The welfare of breeders can illustrate the purchasing power of farmers. The purpose of this study 1) To determine the level of welfare of cattle breeders and 2) To determine the effect of price index factors paid by farmers on the price index received by cattle breeders. This study uses NTP time series data with the base year $2012=100$ as the basis for calculating the years 2018 - 2019. The location studied was determined by purposive sampling method in 5 districts in Sidoarjo Regency which are centers of beef cattle and dairy cows. The sample was selected by purposive random sampling as many as 75 cattle breeders. The NTP analysis method was carried out descriptively and the analysis of the factors that influenced the NTP was carried out using multiple linear regression. The results showed that the exchange rate of cattle farmers in Sidoarjo regency in 2019 increased by 1.81 percent from 109.41 in 2018 to 111.21 in 2019. This shows that cattle breeders in Sidoarjo district are experiencing a surplus or prosperity. The production input price index which includes the price of seeds, feed, and labor wages that must be paid by cattle breeders is a factor that has a significant effect on the cattle price index received by breeders

Keywords: Farmers' Exchange Rates, Welfare, Livestock Subsector, Cattle

\section{INTRODUCTION}

Public welfare is the main indicator that determines the condition of a country, including in developed, developing and underdeveloped countries. This is the background of the stipulation of increasing public welfare as the main goal of national development. As an agricultural country, the number of people involved in agricultural / agribusiness activities is relatively large. Thus increasing the welfare of agricultural communities (farmers) will receive great attention from national development through agricultural development activities. Therefore, in every stage of agri- 
cultural development activities that have been implemented and are currently running, the welfare of farmers has always been one of the main goals and in the future it is believed to be still one of the main priorities / targets of agricultural development. One indicator that can be used to measure the welfare of farmers can use the Farmer Exchange Rate (FER) Nurasa and Rachmat (2016)

Farmer Exchange Rate is the comparison between the price index received by farmers and the price index paid by farmers Kabupaten (2020a).The exchange rate of farmers is also an indicator of production to determine the level of farmer welfare, namely the comparison of the price index received by farmers to the price index paid by farmers Pangestika and Prihtanti (2020). This value can indicate the level of exchangeability of products produced by farmers with products or services needed for agricultural production processes and household consumption. The scope of this NTP includes business activities of food crops, horticulture, plantations and animal husbandry.

Sidoarjo Regency is one of the districts that has constant livestock production in East Java. Population growth is not the only problem that hinders the improvement of farmers' welfare Kabupaten (2020c). Increasing farmers' production and income, with the dominance of their business activities in the livestock sub-sector, is not necessarily followed by an increase in the welfare of farmers if the purchasing power of these farmers does not increase. Linear increase in farmer welfare will be followed by an increase in their purchasing power. The higher the NTP in the livestock subsector will encourage opportunities for increased business undertaken.

Efforts to meet the demand for beef from the population in the country are constrained by the imbalance between supply and demand. This has an impact on increasing the price of beef at the consumer / community level. This condition needs to be anticipated by continuing to strive to develop local livestock, so that there will be an increase in the national population Amalia and Nurpita (2017). Efforts to increase the cattle population should ideally be followed by an increase in the welfare of the breeders which can be measured by the Farmer-Animal Husbandry Exchange Rate (NTP-T) approach. NTP describes the purchasing power / exchange power of farmers to products paid / purchased by farmers, namely products / consumer goods and purchased production inputs. Nurasa and Rachmat (2016). NTP is the purchasing power / exchange power of farmers against goods purchased by farmers where this value shows the real ability of farmers and indicates farmer welfare. Thus, the higher the NTP-T, the better the purchasing power of the breeders so that they are relatively more prosperous Priyono and Magrianti (2017).

NTP-T behavior can be decomposed into its constituent components, especially the price index that must be paid by farmers. This decomposition can be used as a search tool for the determinants of NTP-T rise and fall. Therefore, it is necessary to analyze the factors that determine the fluctuating behavior of NTP-T in national cattle population centers. This information will be important as a consideration for improving the welfare of breeders in line with efforts to accelerate the increase in 
the national cattle population. This study aims to analyze the level of welfare of cattle breeders and to analyze the effect of price index factors paid by farmers on the price index received by cattle breeders in beef and dairy cattle population centers in Sidoarjo Regency.

\section{MATERIALS AND METHODS}

The location studied was determined by a purposive sampling method limited to 5 districts with the highest population of dairy cows and beef cattle in Sidoarjo Regency. The selected locations for the dairy cow population centers consist of Taman and Krian sub-districts, while the selected beef cattle population centers consist of Krian, Tarik and Balongbendo Districts Kabupaten (2020b). The total sample size was 75 breeders, or an average of 15 breeders from each district. The data that will be used in this analysis are qualitative data and quantitative data. Both types of data come from primary data and secondary data. Primary data is obtained through structured interview method using questionnaire tools. Meanwhile, secondary data were obtained through literature study methods, agricultural data consultation, commodity price data and other supporting data. The analytical method used is descriptive analysis, namely the analysis of qualitative and quantitative data, both primary and secondary data. The tools used to perform the analysis are the method of calculating Farmer Exchange Rate, Farming Analysis and Farmers Household Expenditure Structure. The description of each analysis tool is as follows:

NTP = IT $/$ IB

Information:

NTP = Farmer Exchange Rate Index

IT $=$ Price Index received by Farmers

$\mathrm{IB}=$ Price Index Paid by Farmers

This research was conducted using time series data from the Farmers Exchange Rate of Animal Husbandry Indicators (NTP-T) with the base year $2012=100$ as the basis for calculations in December 2018 - December 2019.

Meanwhile, the analysis of the factors that influence the price index paid by farmers for cattle / buffalo on the development of NTP-T in five cattle population center locations uses multiple linear regression analysis. The regression analysis statistical model used in this study, namely:

$\mathbf{Y}=\mathbf{a}+\mathbf{b} 1 \mathbf{X} 1+\mathbf{b} 2 \mathbf{X} 2+\mathbf{b} 3 \mathbf{X} 3+\epsilon$

Information:

$\mathrm{Y}=$ Price index received by cattle / buffalo farmers

$\mathrm{X} 1$ = Price index paid by farmers (IB) for seeds

$\mathrm{X} 2$ = Price index paid by farmers (IB) for medicines and feed

X3 = Price index paid by farmers (IB) for rent and others

$\epsilon=$ Error 


\section{RESULTS AND DISCUSSIONS}

\subsection{CATTLE FARMER EXCHANGE RATE BEHAVIOR IN SIDOARJO REGENCY}

The Exchange Rate of Farmers in Sidoarjo Regency is a proxy indicator to measure the level of welfare of farmers in Sidoarjo Regency. The Farmers Exchange Rate Index is the ratio between the price index received by farmers (IT) and the index of prices paid by farmers (IB). IT and IB are weighted price indexes consisting of the prices of the constituent commodities weighted by the amount of production value that is sold or purchased. In this study, the base year used is 2012. Farmer Exchange Rate in 2012 is equal to $100(2012=100)$.

\subsection{PRICE INDEX RECEIVED BY FARMERS (IT)}

\begin{tabular}{|c|c|c|c|}
\hline Sub Sektor & IT Tahun 2018 & IT Tahun 2019 & Pertumbuhan IT \\
\hline Sektor sapi potong & 105,50 & 106,70 & 1,20 \\
\hline Sektor Sapi Perah & 115,72 & 119,56 & 3.84 \\
\hline IT Kabupaten & 110,61 & 111,71 & 1,10 \\
\hline
\end{tabular}

Sumber: Data analysis, 2019

The price index received by farmers (IT) in Sidoarjo Regency in 2019 shows an increase compared to the price index received by farmers in 2018. The increase in the price index received by farmers in Sidoarjo district was 1.10 percent, from 110.61 in 2018 to 111,71 in 2019 , this is due to an increase in the price index of all sub-sectors, namely the beef cattle sub-sector by 1.20 percent and the dairy cow subsector by 3.84 percent. The price index received by Sidoarjo regency farmers in 2019 was 111.71. This means that farmers' revenues in 2019 increased 1.10 percent compared to revenues in 2018. Prices of livestock commodities have a direct impact on farmer revenues. The price data used is the price of cattle at the farmer level obtained from survey results and structured interviews using a questionnaire to a sample of breeders in 5 sub-districts in Sidoarjo Regency. In addition, price data is also compared and verified through the publication of commodity prices at the regency and provincial level of East Java in 2018 and 2019.

\subsection{PRICE INDEX PAID BY FARMERS (IB)}

The price index paid by farmers (Ib) consists of two groups, namely household consumption and the category of production costs and capital goods formation (BPPBM). The household consumption group is divided into the Food group and the non-Food group. In 2019, the price index paid by beef cattle farmers increased by 0.56 percent compared to 2018, from 100.51 to 101.06 . Meanwhile, at the farmer level, 
Dairy Cows increased by 0.69 percent compared to 2018, from 101.69 to 102.37 . The increase in the price index paid by dairy and beef cattle farmers was due to the increase in the price index for household consumption by 0.61 and 0.65 percent respectively and the price index for the cost of production and purchase of capital goods (BPPBM) of 0 respectively. , 51 and 0.73 percent.

\begin{tabular}{|c|c|c|c|c|c|c|c|}
\hline \multirow[t]{2}{*}{ No } & \multirow[t]{2}{*}{ Uraian } & \multicolumn{3}{|c|}{ Ib Sapi potong } & \multicolumn{3}{|c|}{ Ib Sapi Perah } \\
\hline & & 2018 & 2019 & Growth & 2018 & 2019 & Growth \\
\hline \multicolumn{2}{|c|}{$\begin{array}{l}\text { Indeks Harga Yang } \\
\text { Dibayar Petani (Ib) }\end{array}$} & 100,51 & 101,08 & 0,56 & 101,69 & 102,37 & 0,69 \\
\hline \multirow[t]{7}{*}{1} & $\begin{array}{l}\text { Konsumsi } \\
\text { Rumah } \\
\text { Tangga }\end{array}$ & 100,47 & 101,09 & 0,61 & 102,24 & 102,89 & 0,65 \\
\hline & $\begin{array}{l}\text { a. } \\
\text { Makanan }\end{array}$ & 101,50 & 102,40 & 0,90 & 105,74 & 106,90 & 1,16 \\
\hline & $\begin{array}{l}\text { b. } \\
\text { Peruma- } \\
\text { han }\end{array}$ & 100,42 & 101,25 & 0,83 & 103,25 & 103,90 & 0,65 \\
\hline & c. Sandang & 100,34 & 100,93 & 0,53 & 101,40 & 101,76 & 0,36 \\
\hline & $\begin{array}{l}\text { d. Kese- } \\
\text { hatan }\end{array}$ & 100,45 & 100,80 & 0,35 & 100,67 & 101,42 & 0,75 \\
\hline & $\begin{array}{l}\text { e. Pen- } \\
\text { didikan }\end{array}$ & 99,76 & 100,45 & 0,69 & 100,86 & 101,45 & 0,59 \\
\hline & $\begin{array}{l}\text { f. Trans- } \\
\text { portasi } \\
\& \text { Komu- } \\
\text { nikasi }\end{array}$ & 100,37 & 100,68 & 0,31 & 101,52 & 101,88 & 0,36 \\
\hline \multirow[t]{4}{*}{2} & ВРРВМ & 100,55 & 101,07 & 0,51 & 101,13 & 101,86 & 0,73 \\
\hline & a. Bibit & 100,29 & 101,24 & 0,95 & 101,40 & 102,50 & 1,10 \\
\hline & b. Pakan & 99,85 & 100,24 & 0,39 & 100,30 & 100,98 & 0,68 \\
\hline & $\begin{array}{l}\text { c. Upah } \\
\text { Tenaga } \\
\text { Kerja }\end{array}$ & 101,52 & 101,72 & 0,20 & 101,70 & 102,10 & 0,40 \\
\hline
\end{tabular}

Sumber : Data analysis, 2019

The growth in the exchange rate of cattle breeding in Sidoarjo regency of 1.81 percent was due to the increase in the exchange rates of beef cattle and dairy farmers by 0.60 and 3.00 percent, respectively. Table 3 , explains that the exchange rate of dairy farmers is higher than beef cattle, namely 105.56 and 116.78 respectively. However, these two sub-sectors are categorized as prosperous because they have exceeded the basic limit of 100.The farmer exchange rate in Sidoarjo regency in each sub-sector can be seen in the following Table 3 


\begin{tabular}{|c|c|c|c|c|}
\hline \multirow[t]{13}{*}{ No } & Sub Sektor & 2018 & 2019 & Growth \\
\hline & Gabungan & & & \\
\hline & $\begin{array}{c}\text { Indeks Harga Yang diterima } \\
\text { Petani }\end{array}$ & 110,61 & 113,13 & 2,52 \\
\hline & $\begin{array}{c}\text { Indeks Harga Yang Dibayar } \\
\text { Petani }\end{array}$ & 101,10 & 101,72 & 0,62 \\
\hline & Nilai Tukar Petani (NTP) & 109,41 & 111,21 & 1,81 \\
\hline & Sapi Potong & & & \\
\hline & $\begin{array}{c}\text { Indeks Harga Yang diterima } \\
\text { Petani }\end{array}$ & 105,50 & 106,70 & 1,20 \\
\hline & $\begin{array}{c}\text { Indeks Harga Yang Dibayar } \\
\text { Petani }\end{array}$ & 100,51 & 101,08 & 0,56 \\
\hline & Nilai Tukar Petani & 104,96 & 105,56 & 0,60 \\
\hline & Sapi Perah & & & \\
\hline & $\begin{array}{c}\text { Indeks Harga Yang diterima } \\
\text { Petani }\end{array}$ & 115,72 & 119,56 & 3.84 \\
\hline & $\begin{array}{c}\text { Indeks Harga Yang Dibayar } \\
\text { Petani }\end{array}$ & 101,69 & 102,37 & 0,69 \\
\hline & Nilai Tukar Petani & 113,80 & 116,78 & 3,00 \\
\hline
\end{tabular}

umber: Data analysis, 2019

\subsection{COMPARISON OF FACTORS AFFECTING THE INDEX VALUE RECEIVED BY FARMERS (IT CATTLE)}

Efforts to determine the factors that influence the behavior of the NTP-T value are carried out through the decomposition approach of the price index variable paid by farmers for production costs and the addition of capital goods to the price index received by farmers for beef cattle and dairy cattle Riyadh (2016). The dynamics of the effect of these variables in question resulted in different conditions between beef cattle and dairy cows. The results of the analysis of the effect of the price index paid by farmers with the price index received by farmers are presented in Table 4 .

Table 4 Analysis of the Effect of Price Index Paid by Farmers (IB) to the Price Index Received by Farmers (IT) for Cattle

\begin{tabular}{lcc}
\hline $\begin{array}{l}\text { Variabel Nilai Indeks harga yang } \\
\text { dibayar Petani (IB) }\end{array}$ & Sub Sektor & \\
& Sapi Potong $\left(\mathbf{R}^{2}=\mathbf{0 , 9 3 4 )}\right.$ & Sapi Perah $\left(\mathbf{R}^{2}=\mathbf{0 , 9 5 7}\right)$ \\
Sig. $\mathbf{0 , 0 0 0}$
\end{tabular}

Sumber: Data analysis, 2019

Based on Table 4 , it is known that Beef Cows have a determination coefficient (R2) of 0.934 , which means that $93.4 \%$ of the price index received by farmers is influenced 
by the variables used in the model. The same thing also applies to the coefficient of determination in Dairy Cows which has a R2 value of 0.957 , which means that $95.7 \%$ of the price index received by farmers is influenced by the variables used in the model.

According to Nirmala et al. (2016), Efforts to improve farmer welfare with the farmer exchange rate indicator can be done by increasing production by increasing land area, minimizing household needs, and optimizing input requirements for the production process. Thus, to improve the welfare of breeders can be done by approaching the factors that affect the index of cattle prices received by farmers. The higher the NTP-T value, the higher the purchasing power of the farmers, so that the higher the purchasing power of the farmers, the welfare of the farmers / breeders will increase. Therefore, price policy intervention will have a significant impact on the purchasing power of farmers. This corresponds to Setiawan et al. (2019) that the price and import policies significantly influence the exchange rate of farmers where the effect of price policies on NTP is positive and the effect of imports on NTP is negative.

The NTP-T value is closely related to the input factors of production and the amount of household expenditure. The increasing scale of cattle ownership and the increasing expenditure for household consumption will have an impact on the NTP-T value. This corresponds to Patiung (2018), the number of families and the number of livestock raised have a significant relationship with the welfare of beef cattle farms. Further according to Priyono and Magrianti (2017), Land area, selling price, fertilizer price, and number of family dependents simultaneously and partially have a significant effect on the exchange rate of cassava farmers.

\section{CONCLUSIONS AND RECOMMENDATIONS}

The exchange rate of cattle farmers in Sidoarjo district in 2019 has increased by 1.81 percent from 109.41 in 2018 to 111.21 in 2019 . This shows that the cattle breeders in Sidoarjo district are experiencing a surplus or prosperity. When compared with the base year 2012, the increase in farmer exchange rates was 11.21 percent over a period of 8 years. The production input price index which includes the price of seeds, feed and labor wages that must be paid by cattle breeders is a factor that has a significant effect on the cattle price index received by farmers.

\section{REFERENCES}

Amalia, N., \& Nurpita, A. (2017). ANALISIS DINAMIKA KESEJAHTERAAN PETANI DI PROVINSI JAWA TIMUR. JURNAL AKUNTANSI, EKONOMI dan MANAJEMEN BISNIS, 5(2), 222-222. Retrieved from https://dx.doi.org/10.30871/jaemb.v5i2.574 10.30871/jaemb.v5i2 .574

Kabupaten, S. B. (2020a). Kabupaten Sidoarjo Dalam Angka.

Kabupaten, S. B. (2020b). Nilai Tukar Petani Provinsi Jawa Timur . In N. T. P. P. J. Timur (Ed.), 
Kabupaten, S. B. (2020c). Statistik Kesejahteraan Rakyat Kabupaten Sidoarjo.

Nirmala, A., Hanani, N., \& Muhaimin, A. (2016). Analisis Faktor Faktor yang Mempengaruhi Nilai Tukar Petani Tanaman Pangan di Kabupaten Jombang. In M. N. T. P. T. P. di Kabupaten Jombang (Ed.), HABITAT (Vol. 27, pp. 66-71). Brawijaya University. Retrieved from https://dx.doi.org/10.21776/ub.habitat.2016.027.2.8 10.21776/ub .habitat.2016.027.2.8

Nurasa, T., \& Rachmat, M. (2016). Nilai Tukar Petani Padi di Beberapa Sentra Produksi Padi di Indonesia. Jurnal Agro Ekonomi, 31(2), 161-161. Retrieved from https://dx.doi.org/ 10.21082/jae.v31n2.2013.161-179 10.21082/jae.v31n2.2013.161-179

Pangestika, M., \& Prihtanti, T. M. (2020). PERBANDINGAN NILAI TUKAR PETANI (NTP) ANTARSUBSEKTOR PERTANIAN DI INDONESIA. AGRISAINTIFIKA: Jurnal Ilmu-Ilmu Pertanian, 4(1), 30-30. Retrieved from https://dx.doi.org/10.32585/ags.v4i1.842 10 .32585/ags.v4i1.842

Patiung, M. (2018). ANALISIS NILAI TUKAR PETANI KABUPATEN JOMBANG TAHUN 2018. Jurnal Ilmiah Sosio Agribis, 18(2), 59-71. Retrieved from https://dx.doi.org/10.30742/ jisa.v18i2.517 10.30742/jisa.v18i2.517

Priyono, T., \& Magrianti, R. (2017). Analisis Perkembangan Nilai Tukar Petani Subsektor Peternakan dan Faktor - Faktor yang mempengaruhinya pada Sentra Populasi Sapi di Indonesia. Prosiding Seminar Teknologi dan Agribisnis Peternakan V, 439-451.

Riyadh, M. (2016). Analisis Nilai Tukar Petani Komoditas Tanaman Pangan di Sumatera Utara. J. Ekon. Kebijak. Publik, 6(1), 17-32.

Setiawan, R. A. P., Noor, T. I., Sulistyowati, L., \& Setiawan, I. (2019). Analisis Tingkat Kesejahteraan Petani Kedelai Dengan Menggunakan Pendekatan Nilai Tukar Petani (Ntp) Dan Nilai Tukar Pendapatan Rumah Tangga Petani (Ntprp). JURNAL AGRIBISNIS TERPADU, 12(2), 178-178. Retrieved from https://dx.doi.org/10.33512/jat.v12i2.6779 10.33512/jat.v12i2.6779 